$\underline{\text { Series «Medicine». Issue } 35}$

UDC: 616.98:578.825:612.017:575.22

\title{
PREVALENCE OF POLYMORPHISM OF THE TLR-9 TYPE GENE IN PATIENTS WITH CHRONIC EPSTEIN-BARR VIRUS INFECTION
}

Lyadova T. I., Ognivenko O. V., Volobueva O. V., Gololobova O. V., Malanchuk S. G.

V. N. Karazin Kharkov National University, Kharkiv, Ukraine

The prevalence of polymorphism $-1486 \mathrm{~T} / \mathrm{C}$ of the TLR-9 gene was studied in 44 patients with chronic Epstein-Barr virus infection (CEBV). The control group for the study of the polymorphisms prevalence of $-1486 \mathrm{~T} / \mathrm{C}$ of the TLR-9 gene was 40 healthy donors. Three main genotypes of $-1486 \mathrm{~T} / \mathrm{C}$ of the TLR- 9 gene were identified based on the obtained results - TT, TC, CC. Investigation of the occurrence frequency of individual genotypes revealed the dominance of the TC genotype, compared with the homozygous TT and CC genotypes. The study of $-1486 \mathrm{~T} / \mathrm{C}$ of the TLR-9 gene polymorphism frequency distribution for different genotypes demonstrated the specificity of changes in the TC genotype in patients with CEBV and the absence of such for the TT and CC genotypes. These results confirm the important role of the TLR-mediated signaling in the pathogenesis of the disease, which is necessary to determine the genetic background associated with the course of the disease and its possible consequences. These are the aspects that will further enable the identification of risk groups among such patients and provide timely therapy.

KEY WORDS: chronic Epstein-Barr virus, Toll-like receptors, polymorphism, prevalence

\section{ПОШИРЕНІСТЬ ПОЛІМОРФІЗМУ ГЕНУ ТLR-9 ТИПУ У ХВОРИХ 3 ХРОНІЧНИМИ ФОРМАМИ ЕПШТЕЙНА-БАРР ВІРУСНОЇ ІНФЕКЦІї}

Лядова Т. І., Огнівенко О. В., Волобуєва О. В., Гололобова О. В., Маланчук С. Г.

Харківський національний університет імені В. Н. Каразіна, м. Харків, Україна

Досліджено поширеність поліморфізму -1486T/C гену TLR-9 у 44 пацієнтів 3 хронічними формами Епштейна-Барр вірусної інфекції (ХЕБВ). Контрольна група для вивчення поширеності поліморфізму -1486T/C гена TLR-9 становила 40 здорових донорів. На підставі отриманих результатів виявлено три основних генотипи -1486T/C гену TLR-9 - TT, TC, CС. Аналіз частоти зустрічаємості окремих генотипів виявило домінування генотипу ТС, порівняно з гомозиготним генотипами ТТ та СС. Вивчення розподілу частот зустрічаємості поліморфізму $-1486 \mathrm{~T} / \mathrm{C}$ гену TLR-9 для різних генотипів продемонструвало специфічність змін для генотипу ТС у хворих з ХВЕБ та відсутність таких для генотипів TT та CC. Ці результати підтверджують важливу роль TLR-опосередкованої сигналізації у патогенезі даного захворювання, що $\epsilon$ необхідним для визначення генетичного фону, пов'язаного 3 перебігом хвороби та можливими наслідками ХВЕБ. Саме ці аспекти в подальшому дозволять визначати групи ризику серед таких пацієнтів та провести своєчасну терапію.

КЛЮЧОВІ СЛОВА: вірус Епштейна-Барр, Толл-подібні рецептори, поліморфізм, поширеність

\section{РАСПРОСТРАНЕННОСТЬ ПОЛИМОРФИЗМА ГЕНА ТLR-9 ТИПА У БОЛЬНЫХ С ХРОНИЧЕСКИМИ ФОРМАМИ ЭПШТЕЙНА-БАРР ВИРУСНОЙ ИНФЕКЦИИ}

Лядова Т. И., Огнивенко Е. В., Волобуева О. В., Гололобова О. В., Маланчук С. Г.

Харьковский национальный университет имени В. Н. Каразина, г. Харьков, Украина

Исследована распространенность полиморфизма -1486T/C гена TLR-9 среди 44 пациентов с хроническими формами Эпштейна-Барр вирусной инфекции (ХВЭБ). Контрольная группа для изучения распространенности полиморфизма -1486T/C гена TLR-9 составила 40 здоровых доноров. На основании полученных результатов выявлено три основных генотипа -1486T/C гена TLR-9 - TT, TC, CC. Анализ частоты встречаемости отдельных генотипов выявил доминирование генотипа ТC по сравнению с гомозиготными генотипами ТТ и CC. Изучение распределения частот встречаемости полиморфизма -1486T/C гена TLR-9 для разных генотипов показало специфичность изменений для генотипа ТС у больных с ХВЕБ и отсутствие таковых для генотипов ТТ и СС. Эти результаты подтверждают важную роль TLR-опосредованной сигнализации в патогенезе данного заболевания,

(C) Lyadova T. I., Ognivenko O. V., Volobueva O. V.,

Gololobova O. V., Malanchuk S. G., 2018 
что необходимо для определения генетического фона, связанного с течением болезни и возможными последствиями ХВЭБ. Именно эти аспекты в дальнейшем позволят определить группы риска среди таких пациентов и провести своевременную терапию.

КЛЮЧЕВЫЕ СЛОВА: вирус Эпштейна-Барр, Толл-подобные рецепторы, полиморфизм, распространенность

\section{INTRODUCTION}

To date, scientists have proved that the immune response to the presence of an infectious agent in the human body depends on the type of immunity that is the inherited system of protection against pathogens [1-3] Toll-like receptors (TLRs) are the major signal receptors that are expressed intracellularly and overhead cells: neutrophils, macrophages, dendritic cells, endothelial and epithelial cells, and natural killers (NK) [3-5].

11 TLRs are indicated in mammals, 10 of them are found in humans. The effector cells of the innate immunity express all 10 types of TLRs, each of which binds to the specific ligand [3]. Numerous experimental studies, as well as accumulated results derived from clinical practice, have convincingly proved the key role of Toll-like receptors in the pathogenesis of immunopathological diseases [6-7].

Recognition of bacterial structures (lipopolysaccharide, lipoproteins, peptidoglycan, flagellin etc.) occurs through the activation of TLR-1, 2, 4, 5 and 6 [3, 7]. Four TLR receptors are capable of recognizing nucleic acids - TLR3, 7, 8, and 9, TLR-7 and TLR-8 recognize their own and viral single-stranded RNAs, and TLR9 binds to unmethylated bacteria DNA. TLR-3 is capable of recognizing double-stranded RNA viruses, so this receptor has a key role in the antiviral immune response [3, 8].

Recent studies have made it possible to establish that one of the main causes that may affect the TLR immune response in infectious pathology is the polymorphism of the encoded genes. There is growing evidence that singlenucleotide polymorphism (SNP), due to the formation of specific gene alleles, makes an important contribution to the phenotypic differences among humans, including the individual features of the protective reactions development, as well as the susceptibility to a number of diseases [9-11].

Differences in genes that control the protective response of the body can determine the different course nature of the inflammatory response and specific immunological reactions in contact with foreign structures. First of all it concerns the genes of regulatory molecules that provide the initial stages of the development of inflammatory reactions: pathogen recognition, intracellular activation signal, and the synthesis of inflammatory mediators [5].

Polymorphism of genes suggests that several variants can be copied from the same gene and be structurally different from the copy of the same protein, some of copied variants are either not active, or have the opposite function [12, 13]. Regarding TLR-polymorphism, it has been found that it can lead to a disruption of the infectious agent's recognition, an imbalance in the functioning of the innate immunity system, increased sensitivity to infections and the development of chronic inflammatory processes. Other studies show that the polymorphism of TLR genes due to severe interference with the immune response can determine the severity of the infectious process course, which assumes the nature of the systemic inflammatory response, as well as the development of thanatogenesis [3, 13].

All genes of the TLR-9 subfamily are encoded by two exons. The amino acid sequences of TLR-7 and TLR-8 have a similarity of $72.7 \%$. These amino acids are encoded by genes that are $42.3 \%$ identical and localized on the $\mathrm{X}$ chromosome (Chr22). The TLR-9 gene is on the short shoulders of the third chromosome (3r21.3) and is bound to genes such as MYD88 and CAMP that are in the region containing tumor growth genes [13]. The protein products of all of the genes mentioned above play an important role in the reactions of innate immunity either in direct protection (LL-37) or in signals conduction in the cell (MyD88, NF-kB).

Different works emphasize the polymorphism association of the TLR-2 and TLR-9 genes with infectious diseases. It is known that such polymorphism of the TLR-2 gene as Arg753Gln, T597C is associated with infections caused by Candida albicans, $\mathrm{M}$. tuberculosis, cytomegalovirus (CMV), herpes simplex virus type 1 and type 2 (HSV-1 and HSV-2) and others pathogens [8, 11, 14-15]. The polymorphism of the TLR-9 gene, that 
includes G1174A, G1635A and A2848G, is associated with systemic lupus erythematosus, the development of an infection caused by HIV1 and other diseases [8]. Listed above polymorphisms are located both in the LRR domain of the TLRs that recognizes the pathogen and in the TIR domain involved in the signal in the cell.

A number of studies have demonstrated the role of TLR in the pathogenesis of Lyme disease. Lipoproteins of Borrelia, in particular OspA, potentially activate inflammatory response by binding to CD14 and TLR-2 expressed on macrophages. As a result, TLR-2, TLR-6, TLR-1/2, TLR-5, and TLR-9 receptors induce the secretion of macrophage mediated proinflammatory cytokines. The TLR-2/TLR-6, TLR-2/TLR-1 receptor dimers are involved in the activation of the nuclear transcription factor $\mathrm{NfkB}$ through the recognition of triacylated lipoproteins, such as Borrelia burgdorferi OspA, flagellin, peptidoglycans and zymosan $[3,8,13]$.

Edyta Paradowska et al. investigated the polymorphism of genes (-1237T/C, rs5743836; -1486T/C, rs187084, 1174G/A, rs352139 and $2848 \mathrm{C} / \mathrm{T}$, rs352140) among 72 children with CMV infection in their work. The authors established an increased frequency of heterozygous -1486 T/C and $2848 \mathrm{C} / \mathrm{T}$ genotypes of TLR-9 in infants with CMV infection compared with non-infected cases. The heterozygous variants of these two SNPs increased the risk of CMV disease in children. The obtained data indicate that $-1486 \mathrm{~T} / \mathrm{C}$ and $2848 \mathrm{C} / \mathrm{T}$ polymorphisms of TLR-9 may be a genetic risk factor for the development of CMV-induced infection [16].

However, there is an insufficient amount of conducted studies on the prevalence of different types of TLR gene polymorphism in patients with EBV infection in the contemporary scientific literature.

\section{OBJECTIVE}

Investigate the frequency of the $1486 \mathrm{~T} / \mathrm{C}$ polymorphism of TLR-9 gene in patients with chronic Epstein-Barr virus infection (CEBV).

\section{MATERIALS AND METHODS}

The study had been performing at the Department of General and Clinical Immunology and Allergology of the Medical Faculty of Kharkiv National University named V. N. Karazin and clinical base of the
Department - Regional Clinical Hospital of Infectious Diseases, in Kharkiv during 20092016 in the framework of the research topic: «Study of the role of immune, autoimmune and metabolic disorders in the pathogenesis and consequences of the infection process caused by herpes viruses» No.0112U005911 of state registration.

Complete blood count and biochemical profile were carried out for all patients in the dynamics of the disease. The material for the study was the serum of patients with EpsteinBarr virus (EBV) infection, which was obtained during the period of the disease. Blood for research was collected from the elbow vein in the amount of $10 \mathrm{ml}$ in a sterile Eppendorf tube.

Specific antiviral antibodies (VCA-IgM, EA-IgM and EBNA-IgG) in serum were determined by the solid phase enzyme-linked immunosorbent assay (ELISA) with production sets produced by Vector-Best (Novosibirsk, Russian Federation) and IBL (Hamburg, Germany) according to the instructions given. Some patients were serologically screened for HSV-1, HSV-2, CMV, toxoplasma, hepatitis viruses (A, B and C), and HIV for differential diagnosis. For this purpose, the following test systems for solid-phase ELISA were used: antiHAV-IgM, anti-CMV-IgM, anti-Toxo-IgM, HBsAg, anti-HCV-total and anti-HIV-1 + 2total, produced by: «Vector-Best» (Novosibirsk, Russian Federation), «IBL» (Hamburg, Germany).

«AmpliSens» reagents sets (Moscow, Russian Federation) were used for the detecting the DNA of the EBV by PCR with reverse transcription with hybridization and fluorescence detection of amplification products. The isolation of the DNA from the specimens was carried out using a kit for DNA extraction made by the «Miniprep» (Sillex M, Russia) using the method of sorption of DNA on sorbent by Boom R. et al., 1990. DNA amplification was performed using the kit «DNA amplification» (Silex-M, Moscow) on the BIC amplifier.

Genomic DNA was isolated using the «Plasma/serum DNA/RNA extraction kit» (LitTech, Russia).

A polymorphic site of $-1486 \mathrm{~T} / \mathrm{C}, \mathrm{rs} 187084$ of the TLR9 gene was found by real-time PCR amplification by determining the restriction fragment length (RFLP)-PCR using Ncol restriction enzymes and oligonucleotide primers. DNA primers for target genes were 
selected using the GeneRunner v.3.0 program and synthesized by the LitTech, Russia.

The serum concentrations of the studied cytokines (CK): IJI-1 $\beta$, TNF- $\alpha$, IL-6, IL-2, IL-4, IL-10 were determined using the test systems made by the «Protein Contour» Ltd (SaintPetersburg, Russian Federation), using the manufacturer's instructions and solid-phase ELISA.

The results of the research were processed by the method of variation and correlation statistics using the Statistika 10.0 for Windows program (Stat Soft Inc, USA). The average arithmetic $(\mathrm{M})$, the mean square deviation $(\sigma)$ and the average error of the arithmetic mean (m) were calculated for each variation series. Methods of parametric and nonparametric statistics were also used. Quantitative and qualitative analysis of intra-system and intersystem correlation connections were carried out using the method of correlation structures and the sequential analysis of Wald.

The distribution of genotypes was determined by applying the Hardy-Weinberg Law, the population genetics law, which allows assessing the population risk of genetically determined diseases, since each population has its own set of allele fund and, accordingly, a different frequency of unfavorable alleles. The distribution of the investigated polymorphic genotypes was checked for compliance with the Hardy-Weinberg equilibrium using the $\chi^{2}$ criterion.

The comparison of the frequencies of alleles and genotypes between the groups was carried out by analyzing the conjugation tables using the Fisher's exact test. The odds ratio (OR) was calculated with a $95 \%$ confidence interval (CI) in order to compare the frequency of variants in unbound groups. Relative risk of disease and complications was estimated using the OR parameter. The OR and $95 \%$ confidence intervals was calculated using Odds ratio calculator. The indicator $\mathrm{OR}=1$ was considered as a lack of association; OR > $1-$ as a positive association («predisposition»), OR $<1-$ as a negative association of allele or genotype with the disease.

\section{RESULTS AND DISCUSSION}

Diagnosis CEBV was conducted by clinical symptoms, complaints and laboratory results. Clinical signs that indicate active virus infection: fever, lymphadenopathy, presence of chronic inflammatory lesions in the oropharynx and nasopharynx, asthenia symptoms were taken into account. In addition, the severity and features of the mononucleosis syndrome were assessed, and the presence of concomitant pathology manifestations was taken into account.

The provisions of the World Medical Association Declaration of Helsinki, Code of Ethics of a doctor of Ukraine, informing the patient about the nature of the study were adhered during the study. The clinical diagnosis of the patients included in the study was defined as B27 according to the International statistical classification of diseases, 10th revision (version 2007). The verification of the clinical diagnosis of infectious mononucleosis (IM) in patients older than 18 years was conducted in accordance with the recommenddations of Zh. I. Vozianova et al. (2001).

The criteria for selecting patients in the CEBV group were such complaints as fatigue, general weakness, emotional lability, depressive states, insomnia, headache, chills, throat discomfort, and muscle pain. In the clinical examination, attention was paid to the enlargement of lymph nodes, subfebrile fever, hyperemia of the oropharynx. In some patients, hepatosplenomegaly was noted.

Etiotropic therapy included valacyclovir $1000 \mathrm{mg} 3$ times a day in different groups and immunomodulatory drug allokin-alpha $1.0 \mathrm{ml}$ subcutaneously once every two days (course 6 injections). The effectiveness of the therapy was assessed in patients with EBV infection on the basis of clinical data, achievement of biochemical, laboratory and virological remission (disappearance of the DNA of the EBV or decrease of the level of viremia).

Characteristic of the main clinical forms in patients with CEBV is presented in Table 1.

Analysis of the data presented in the table 1 allowed to establish that the most frequent clinical syndrome among patients with CEBV was asthenovegetative, which manifested in patients complaints about a general weakness in $69 \%$ of cases, fatigue in $73 \%$, headache in $85 \%$, sleep disorders in $45 \%$, and respiratory tract involvement in the form of tonsillitis and pharyngitis more than 3 times a year in $72 \%$. Lymphadenopathy syndrome was found in 121 patients with CEBV. It was characterized predominantly by an enlargement of anterior and posterior lymph nodes. Clinical symptoms of arthralgia, myalgia, neuralgia and meningeal symptoms were diagnosed in $49.7 \%$ of patients 
with CEBV. The syndrome of subfebrile condition was characterized by body temperature variations during the day from $37.2{ }^{\circ} \mathrm{C}$ to $37.5^{\circ} \mathrm{C}$ and was observed in
90 patients with CEBV. And hepatolial syndrome was confirmed in this category of patients only in almost $10 \%$ of cases.

Table 1

Characteristics of the main clinical forms in patients with HBEB

\begin{tabular}{|l|c|c|}
\hline \multicolumn{1}{|c|}{ Clinical symptoms } & Absolute quantity $(\mathrm{n}=183)$ & Interest $(\%)$ \\
\hline Asthenovegetative syndrome & 183 & 100 \\
\hline Damage of lymphoid tissue of the pharynx & 132 & 72 \\
\hline Peripheral lymphadenopathy & 121 & 66,1 \\
\hline Arthralgia, myalgia, neuralgia & 91 & 49,7 \\
\hline Durable subfebrile & 90 & 49,1 \\
\hline Hepatolial syndrome & 18 & 9,8 \\
\hline
\end{tabular}

In most patients, clinical trial data indicated polymorphism and nonspecific clinical manifestations, however, they last ones were characterized by persistence and durability.

Indicators in the complete blood count were characterized by the normal amount of leukocytes, the average number of which was $5.7 \pm 1.9 \times 109 / 1$. Lymphocytosis and monocytosis were indicated in more than $2 / 3$ of patients with CEBV, that is $64.7 \%$ and $62.4 \%$ respectively. The average percentage of lymphocytes was $39.5 \pm 2.1 \%$, and monocytes $-11.3 \pm 0.9 \%$, respectively.

Research to determine polymorphism 1486 T/C of TLR-9 gene was conducted on 44 patients with CEBV. Among them, women amounted to 25 (56.8 \%), men - 19 (43.2\%) aged from 18 to 44 years. The control group for studying the prevalence of $-1486 \mathrm{~T} / \mathrm{C}$ polymorphism of TLR- 9 gene consisted of 40 healthy donor individuals. The average age was $24.2 \pm 2.4$ years, in the range from 18 to 44 years.

Distribution of patients and healthy people by age and gender is presented in Table 2 .

The following genotypes $-1486 \mathrm{~T} / \mathrm{C}$ gene TLR-9 - TT, TS, CC were obtained as a result of the molecular-genetic survey of 44 patients with CEBV and patients of the control group.

Distribution of surveyed by age and gender, abs. number, (\%)

Table 2

\begin{tabular}{|l|c|c|c|c|c|c|c|c|}
\hline \multirow{3}{*}{ Age, years } & \multicolumn{3}{|c|}{ Patients with CEBV $(\mathbf{n}=\mathbf{4 4})$} & \multicolumn{4}{c|}{ Control (n= 40) } \\
\cline { 2 - 9 } & \multicolumn{2}{|c|}{ men } & \multicolumn{2}{c|}{ women } & \multicolumn{2}{c|}{ men } & \multicolumn{2}{c|}{ women } \\
\cline { 2 - 9 } & $\mathrm{n}$ & $\%$ & $\mathrm{n}$ & $\%$ & $\mathrm{n}$ & $\%$ & $\mathrm{n}$ & $\%$ \\
\hline $\mathbf{1 8}-\mathbf{2 4}$ & 4 & 21,1 & 7 & 28 & 10 & 45,4 & 9 & 50 \\
\hline $\mathbf{2 5}-\mathbf{3 4}$ & 10 & 52,6 & 10 & 40 & 6 & 27,3 & 5 & 27,8 \\
\hline $\mathbf{3 5 - 4 4}$ & 5 & 26,3 & 8 & 32 & 6 & 27,3 & 4 & 22,2 \\
\hline Total: & 19 & 43,2 & 25 & 56,8 & 22 & 55 & 18 & 45 \\
\hline
\end{tabular}

The frequency of distribution of the 1486T/C SNP in TLR-9 gene in patients with CEBV was as follows: TT genotype $-11 \%$ (5 patients), TC $-73 \%$ (32 patients) and CC $-16 \%$ (7 patients). In the control group, the wild type genotype TT was detected in $40.0 \%$ (16 patients), the heterozygous genotype TC - in $45.7 \%$ (18 patients), while the homozygous $\mathrm{CC}$ genotype was found in $14.3 \%$ (6 patients).
It should be noted that the homozygous CC genotype was verified almost with the same frequency among the groups of patients being studied, while the homozygous TT genotype, on the contrary, was more frequently found in the control group of patients. The heterozygous TC genotype was significantly often verified in the group of patients with CEBV (Fig. 1). 


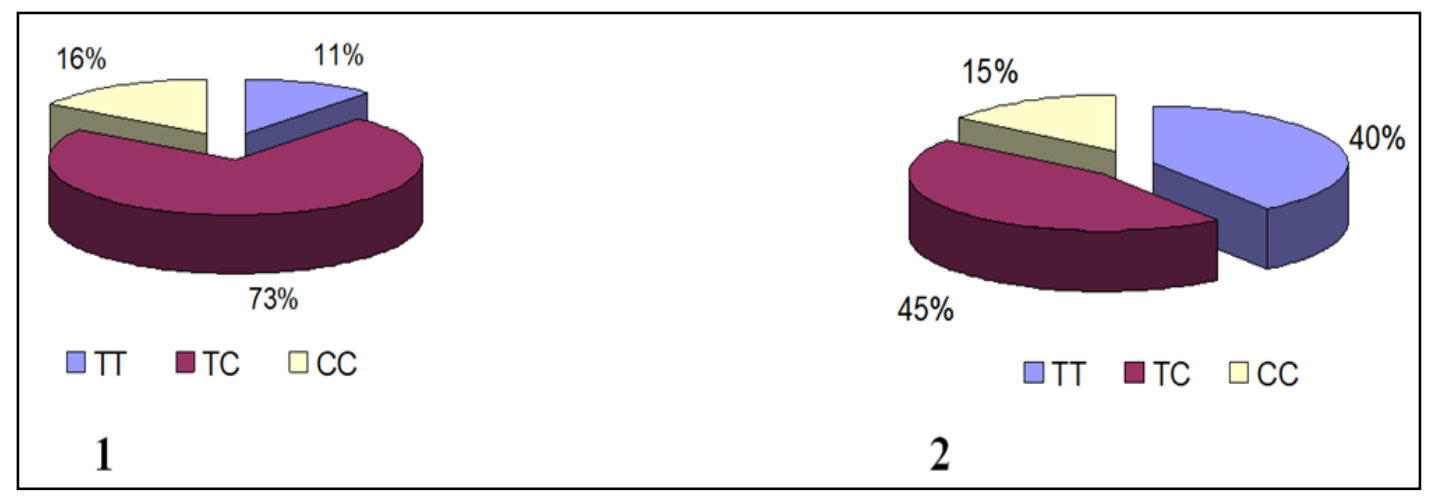

Fig. 1. Frequency of individual genotypes -1486 T/C TLR-9 gene in patients with HBEB (1) and control group (2)

The occurrence frequency of $-1486 \mathrm{~T} / \mathrm{C}$ genotype of the TLR-9 gene - TT, TC, CC are given in Table 3 in the form of percent $(\mathrm{P})$ \pm standard deviation of the percentage (SdP for binomial distribution) and the results of the Student's t-test.

As can be seen from the table, the occurrence frequency of TT-1486T/C genotype TLR-9 gene differed significantly in comparison to the same data of the control group and was $11 \pm 31$ versus $40 \pm 49$ $(\mathrm{p}<0.05)$. Also, the studied index was statistically significantly different from that of the control group for the TC genotype and was $73 \pm 44$ and $45 \pm 50(\mathrm{p}<0.05)$. There was no statistically significant difference in the incidence rate of the CC-1486T/C genotype TLR-9 gene from the control group's parameters $-16 \pm 37$ versus $15 \pm 36$ $(\mathrm{p}>0.05)$.

Table 3

The frequency of genotypes -1486 T / C TLR-9 gene - TT, TS, SS, P (\%) $\pm \sigma$

\begin{tabular}{|c|c|c|}
\hline TLR-9 rs187084 C/T & Patients with CEBV $(\mathbf{n}=\mathbf{4 4})$ & $\begin{array}{l}\text { Control } \\
(\mathbf{n}=\mathbf{4 0})\end{array}$ \\
\hline TT & $11 \pm 31^{1}$ & $40 \pm 49$ \\
\hline TC & $73 \pm 44^{1}$ & $45 \pm 50$ \\
\hline CC & $16 \pm 37$ & $15 \pm 36$ \\
\hline
\end{tabular}

Note:

1 - Reliable probability from the control group at p-value $<0.05$

The distribution of the occurrence frequencies of genotypes for patients with CEBV and patients in the control group are given in table 4 according to the results of statistical analysis.

Statistically significant differences at $\mathrm{p}<0.05$ were found for the genotypes of TT and TC in the group of patients with CEBV and control group through the analysis of the frequency distribution of genotype $-1486 \mathrm{~T} / \mathrm{C}$
TLR-9 gene in patients with IM. Thus, for the homozygous genotype of TT, this indicator was $11 \%$ vs. $40 \%(p<0,05)$, for the genotype TC $73 \%$ vs. $45 \% \quad(\mathrm{p}<0,05)$, whereas for the CC genotype, the frequency distribution did not have statistically significant differences compared to the control group and was found in the studied groups of patients with the same frequency of $16 \%$ vs. $15 \%(\mathrm{p}>0.1)$.

Table 4

Distribution of genotype frequencies -1486 T/C TLR-9 gene in patients with CEBV

\begin{tabular}{|l|c|c|c|c|c|}
\hline $\begin{array}{c}\text { TLR-9 } \\
\text { rs187084 C/T }\end{array}$ & $\begin{array}{c}\text { Patients with } \\
\text { CEBV (n= 44) }\end{array}$ & $\begin{array}{c}\text { Control } \\
(\mathbf{n}=\mathbf{4 0})\end{array}$ & $\begin{array}{c}\text { Fischer's } \\
\text { criterion }\end{array}$ & $\begin{array}{c}\text { OR (odds } \\
\text { ratio) }\end{array}$ & 95 \% CI \\
\hline TT & $5(11 \%)$ & $16(40 \%)$ & $\mathrm{p}<0,05$ & 0,19 & $0,06-0,59$ \\
\hline TC & $32(73 \%)$ & $18(45 \%)$ & $\mathrm{p}<0,05$ & 3,26 & $1,3-8,1$ \\
\hline CC & $7(16 \%)$ & $6(15 \%)$ & $\mathrm{p}>0,1$ & 1,07 & $0,33-3,5$ \\
\hline
\end{tabular}


According to the calculated odds ratio, the presence of the heterozygous TC genotype (CI: $1.3-8.1$ and $\mathrm{OR}=3.26$, respectively) in the genome of patients with CEBV is specific for patients with CEBV, that allows it to be assessed as a positive association, compared to the obtained indices for homozygous TT types (CI: $0.06-0.59$ and $\mathrm{OR}=0.19$ ) and the CC genotype (CI: $0.33-3.5$ and $\mathrm{OR}=1.07$, respectively) that are evaluated as a negative association of genotypes with chronic forms of EBV infection.

We analyzed the frequency of individual allelic variations, depending on the type of immune response to determine the effect of the 1486 T/C of TLR-9 gene on the production of proinflammatory and antiinflammatory CK.
Data on the detection of a combination of alleles in patients with CEBV are presented in table 5.

Two types of immune response: dissociative, which was characterized by a slight increase in proinflammatory IL-1 $\beta$, TNF- $\alpha$, IL- 6 and regulatory IL-2 and a significant increase in anti-inflammatory IL-4 and IL-10; and hyporeactive - low concentrations of both proinflammatory and antiinflammatory CK were found according to the levels of the CK in 80 patients with CEBV. Dissociation type was detected in $58.7 \%$ (47 patients) with CEBV, the hyporeactive type was found in $41.3 \%$ (33 patients), from the total number of subjects. A study to determine the effect of 1486T/C polymorphism of the TLR-9 gene was performed on 44 patients with CEBV.

Table 5

Occurrence frequency of allelic variations of $1486 \mathrm{~T} / \mathrm{C}$ gene of TLR-9 gene in patients with CEBV with different types of immune response (n, \%)

\begin{tabular}{|l|c|c|c|c|c|c|}
\hline \multirow{2}{*}{ Type of immune response (n=44) } & \multicolumn{2}{|c|}{ TT } & \multicolumn{2}{c|}{ TC } & \multicolumn{2}{c|}{ CC } \\
\cline { 2 - 7 } & abs. & $\%$ & abs. & $\%$ & abs. & $\%$ \\
\hline Dissociative type (n=28) & 1 & 2,3 & 20 & 45,5 & 7 & 15,9 \\
\hline Hyporeactive type (n=16) & 4 & 9,1 & 12 & 27,3 & - & - \\
\hline Total: & 5 & 11,4 & 32 & 72,8 & 7 & 15,9 \\
\hline
\end{tabular}

As can be seen from Table 5, the frequency of T-alleles detection was $84.1 \%$ (37 patients) on CEBV, the incidence of $\mathrm{C}$ alleles was $88.6 \%$ (39 patients).

Data analysis of table 5 and fig. 2 allowed establishing that the heterozygous TC genotype was found to be the dominant genotype among patients with CEBV, which was found in $71.4 \%$ of patients with dissociation type of immune response and in $75 \%$ of patients with hyporeactive type of immune response.

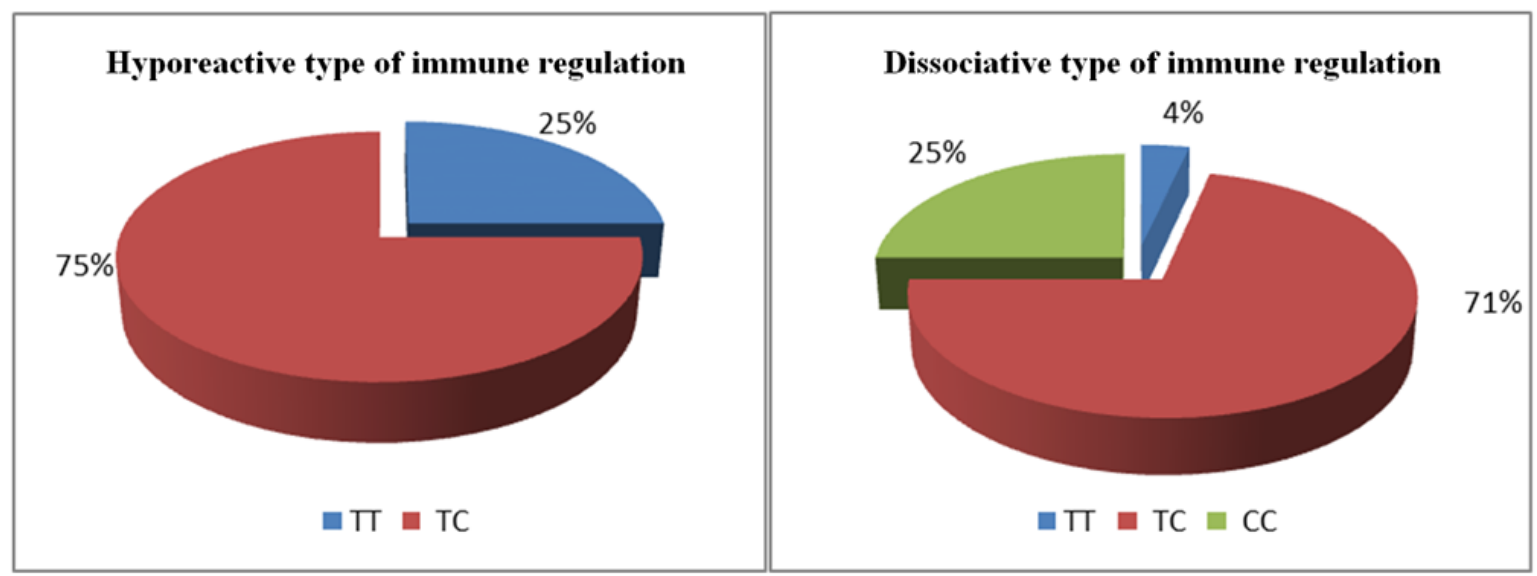

Fig. 2. Occurrence frequency of allelic variations of $1486 \mathrm{~T} / \mathrm{C}$ gene of TLR-9 gene in patients with $\mathrm{CEBV}$ with different types of immune response (\%) 


\section{CONCLUSIONS}

The analysis of the results of the $-1486 \mathrm{~T} / \mathrm{C}$ polymorphism of the TLR-9 gene revealed three main genotypes - TT, TC, CC. Investigation of the occurrence frequency of individual genotypes revealed the dominance of the genotype TC, compared with the homozygous genotypes of TT and CC. The study of frequency distribution of the polymorphism -1486T/C of TLR-9 for different genotypes demonstrated the specificity of changes in the TC genotype and the absence of such in the TT and CC genotypes in patients with CEBV.

Our study for the purpose of determining the 1486T/C polymorphism of the TLR-9, that is associated with chronic forms of CEBV infection, confirms the important role of TLR-mediated signaling in the pathogenesis of this disease, which is necessary to determine the genetic background associated with the course of the disease and possible consequences of CEBV.
These aspects will further enable the identification of risk groups among such patients and provide timely therapy.

Analysis of the results allowed establishing the following:

1. The $1486 \mathrm{~T} / \mathrm{C}$ polymorphism of the TLR-9 gene is significantly more frequent in patients with CEBV than in the control.

2. The frequency distribution of the 1486T/C polymorphism of the TLR-9 gene allowed the establishment of the association of the genotype TC with chronic forms of the EBV infection, which is very specific for this group of patients.

\section{PROSPECTS FOR FUTURE STUDIES}

It seems advisable to study differences in the immune response, the development of complications and the activity of the process in patients with CEBV and various 1486T/C polymorphism of TLR-9 gene in patients with chronic Epstein-Barr virus infection (CEBV) and drug correction depending on the results.

\section{REFERENCES}

1. Brubaker S. W. et al. Innate immune pattern recognition: a cell biological perspective // Annual review of immunology. - 2015. - V. 33. - p. 257-290.

2. Lester S. N., Li K. Toll-like receptors in antiviral innate immunity // Journal of molecular biology. -2014 . - V. 426. - No. 6. - p. 1246-1264.

3. Kawai T., Akira S. The role of pattern-recognition receptors in innate immunity: update on Toll-like receptors // Nature immunology. - 2010. - V. 11. - No. 5. - p. 373.

4. Kawasaki T., Kawai T. Toll-like receptor signaling pathways // Frontiers in immunology. - 2014. - V. 5. p. 461.

5. De Nardo D. Toll-like receptors: Activation, signaling and transcriptional modulation // Cytokine. -2015. - V. 74. - No. 2. - p. 181-189.

6. Achek A., Yesudhas D., Choi S. Toll-like receptors: promising therapeutic targets for inflammatory diseases // Archives of pharmacal research. - 2016. - V. 39. - No. 8. - p. 1032-1049.

7. Satoh T., Akira S. Toll-Like Receptor Signaling and Its Inducible Proteins // Microbiology spectrum. 2016. - V. 4. - No. 6.

8. Beima-Sofie K. et al. Toll-like receptor 9 polymorphism is associated with increased Epstein-Barr virus and Cytomegalovirus acquisition in HIV-exposed infants // Aids. - 2018. - V. 32. - No. 2. - p. 267-270.

9. Skevaki C. et al. Single nucleotide polymorphisms of Toll-like receptors and susceptibility to infectious diseases // Clinical \& Experimental Immunology. - 2015. - V. 180. - No. 2. - p. 165-177.

10. Schnetzke U. et al. Polymorphisms of Toll-like receptors (TLR2 and TLR4) are associated with the risk of infectious complications in acute myeloid leukemia // Genes and immunity. - 2015. - V. 16. - No. 1. p. 83.

11. Lai Y. F. et al. Functional polymorphisms of the TLR7 and TLR8 genes contribute to Mycobacterium tuberculosis infection // Tuberculosis. - 2016. - V. 98. - p. 125-131.

12. Drutskaya, M. S. Vrozhdennoye raspoznavaniye virusov [Tekst] / M. S. Drutskaya, P. V. Belousov, S. A. Nedospasov // Molekulyarnaya biologiya. -2011. - V. 25, No. 3. - p. 7-19.

13. Barton, G. M. Viral recognition by Toll-like receptors [Text] / G. M. Barton // Seminars in Immunology. 2007. - Vol. 19, Issue 1. - P. 33-40.

14. Choteau L. et al. Role of TLR1, TLR2 and TLR6 in the modulation of intestinal inflammation and Candida albicans elimination // Gut pathogens. - 2017. - V. 9. - No. 1. - p. 9. 
15. Mukherjee S., Karmakar S., Babu S. P. S. TLR2 and TLR4 mediated host immune responses in major infectious diseases: a review //Brazilian Journal of Infectious Diseases. - 2016. - V. 20. - No. 2. - p. 193204.

16. Paradowska, E. TLR9 -1486T/C and 2848C/T SNPs Are Associated with Human Cytomegalovirus Infection in Infants [Text] / E. Paradowska, A. Jabłońska, M. Studzińska, K. Skowrońska, P. Suski, M. Wiśniewska-Ligier et. al. // PLOS ONE. - 2016. - Vol. 11, Issue 4. - P. e0154100. 